\title{
Comparison of hematological findings in H1N1 infections with hematological findings in other viral agents
}

\author{
H1N1 Enfeksiyonlarında görülen hematolojik bulguların diğer viral \\ etkenlerde görülen hematolojik bulgularla karşılaştırılması
}

\author{
Hakan SARBAY
}

\section{ABSTRACT}

Introduction: In this study, the hematologic findings of patients who were diagnosed with H1N1 virus infection and their effects on the course of the disease were reviewed.

Method: Twenty-one children who received diagnosis of H1N1 infection were included in the study. Blood count results on days 1,3 and 7 were examined. The frequency of the $1^{\text {st }}$ day hematologic findings of the patients was compared with those of 3 groups in the same age and the same number of patients. Time of onset of hematologic findings and prognostic effects were evaluated.

Results: Seven of the 21 patients (33.3\%) were female, and 14 (66.7\%) were male. The mean age was 5.1 years. Seven patients (33.3\%) had leukopenia, 3 (14.3\%) had leukocytosis, and 4 (19\%) had anemia. Nine patients (42.9\%) had thrombocytopenia, and 1 patient (4.8\%) had thrombocytosis. Lymphopenia was detected in 9 patients (42.9\%), neutropenia in 3 (14.3\%), and monocytosis in 8 patients (38.1\%). Three patients who had underlying chronic disease or respiratory distress died during the follow-up period.

Conclusion: In conclusion, more frequent and severe cytopenias seen in H1N1 infections are thought to cause the clinical presentation to be more severe.

Keywords: H1N1, hematological findings, thrombocytopenia
Öz

Giriş: Bu çalışmada, kliniğimizde değerlendirilen ve H1N1 virüs enfeksiyonu tanısı alan hastaların hematolojik bulguları ve hastalığın gidişatına etkileri gözden geçirildi.

Yöntem: H1N1 enfeksiyon tanılı 21 çocuk çalışmaya dahil edildi. Kan sayımı sonuçları 1., 3. ve 7. günlerde incelendi. Hastaların 1. gün hematolojik bulgularının sıklığı, aynı yaş ve aynı sayıda hastadaki 3 grup ile karşılaştırıldı.

Bulgular: Hastaların yedisi $(\% 33,3)$ kIz, 14'ü $(\% 66,7)$ erkekti. Ortalama yaş 5,1 olarak saptandı. Hastaların yedisinde $(\% 33,3)$ lökopeni, üçünde $(\% 14,3)$ lökositoz, dördünde (\%19) anemi bulunmaktaydı. Dokuz hastada $(\% 42,9)$ trombositopeni, bir hastada da $(\% 4,8)$ trombositoz mevcuttu. Dokuz hastada $(\% 42,9)$ lenfopeni saptanırken, üç hastada $(\% 14,3)$ nötropeni, sekiz hastada $(\% 38,1)$ monositoz saptandı. Altta yatan kronik hastalığı olan, izlemlerinde solunum sıkıntısı ve çoklu organ yetersizliği gelişen üç hasta kaybedildi.

Sonuç: Sonuç olarak, H1N1 enfeksiyonlarında sitopenilerin daha sık görülmesi ve ağır olmasının klinik tablonun daha ağır seyretmesine neden olabileceği düşünülmektedir.

Anahtar kelimeler: H1N1, hematolojik bulgular, trombositopeni

\section{INTRODUCTION}

The pandemic influenza (H1N1) virus causes significant disease in children with symptoms such as fever, cough, headache, sore throat, myalgia, vomiting, and diarrhea. H1N1 infections are major causes of death and illness, especially in children under the age of 2 and in those who have chronic diseases or immunosuppression. Respiratory failure is the main finding in severe H1N1 infections ${ }^{1}$. Real-time reverse

Received: 11.04 .2018

Accepted: 25.07 .2018

Diyarbakır Children Hospital Department of Pediatric Hematology and Oncology, Diyarbakır, Turkey

Yazışma adresi: Hakan Sarbay, Diyarbakır Children Hospital Department of Pediatric Hematology and Oncology, Diyarbakır, Turkey

e-mail: drhakansarbay@hotmail.com

Yazarın ORCiD bilgileri:

H.S. $0000-0002-6332-2213$ 
transcriptase-polymerase chain reaction is used for the detection of H1N1 infection. Preferred examples are nasopharyngeal or oropharyngeal swabs, nasal aspirate, or both nasopharynx and oropharyngeal swabs ${ }^{1,2}$. The use of neuraminidase inhibitors is recommended in high-risk patients due to complications of HIN1 infections, and high risk of death ${ }^{3}$. Cytopenia, leukocytosis, lymphocytosis, hemophagocytosis, and coagulation disorders can develop during the course of H1N1 infections. These findings are usually seen early in the course of the disease ${ }^{4}$. In this study, hematological findings of patients who received diagnoses of $\mathrm{H} 1 \mathrm{~N} 1$ virus infections were reviewed.

\section{MATERIAL and METHODS}

Between December 2015 and January 2016, 21 children with the diagnosis of H1N1 infection were included in the study. The patients consisted of children who were hospitalized with fever and pneumonia in different age groups. The H1N1 virus was detected through a polymerase chain reaction analysis of nasopharyngeal aspiration in patients who had follow-up appointments at our clinic after experiencing fever and infection. Each patient's age, gender, initial complaints, physical examination findings, and underlying disease were recorded. According to the results of the blood counts on days 1,3 , and 7 after the initial examination, the onset time for each hematologic finding and the time it took for each to return to normal levels were evaluated together with the clinical course. The cut-off values for hematological parametres were as follows: leukopenia $<4000 /$ $\mu \mathrm{L}$, leukocytosis $>12.000 / \mu \mathrm{L}$, neutropenia $<1000 / \mu \mathrm{L}$ under 1 year, <1500/ $\mu \mathrm{L}$ over 1 year, lymphopenia $<1500 / \mu \mathrm{L}$, monocytosis $>800 / \mu \mathrm{L}$ thrombocytopenia $<150,000 / \mu \mathrm{L}$, thrombocytosis $>450,000 / \mu \mathrm{L}$ and anemia below -2 SD according to age.

The frequency of the $1^{\text {st }}$ day hematologic findings of the patients was compared with those of the 3 groups with the same age and the same number of patients. Group 2 consisted of 21 patients with EBV diagnosed in different complaints. 21 patients with
CMV, adenovirus, rotavirus, hepatitis A, parvovirus infection were included in Group 3. The Groups 2 and 3 consisted of patients who were hospitalized due to fever, gastroenteritis, respiratory tract infection, and viral agents were detected by serological tests. In Group 4, the blood count results of healthy children were used.

The study was approved by the Ethics Committee. Written informed consent was obtained from the parents of all patients. Descriptive statistics were used to describe continuous variables. (mean, standard deviation, minimum, median, maximum, $\mathrm{N}$ (frequency), percent). Chi-Square was used to examine the relationship between categorical variables. Level of statistical significance was determined as 0.05 . Analyzes were performed using MedCalc Statistical Software version 12.7.7 (MedCalc Software bvba, Ostend, Belgium).

\section{RESULTS}

Seven of the 21 patients (33.3\%) were female, and $14(66.7 \%)$ were male. The mean age was $5.1 \pm 5.6$ years. The youngest patient was 1 month old, and the oldest patient was 17 years old. The most common complaints were fever $(90 \%)$, sore throat $(66 \%)$, cough (58\%), respiratory distress (45\%), and abdominal pain (33\%). The mean time between the onset of complaints and hospital admission was 2 days (range, 1-4 days). Ten of the patients (47\%) had underlying chronic diseases such as neurological diseases in 4 (19\%), chronic lung diseases in 2 (9.5\%), congenital heart disease in $3(14.2 \%)$ and chronic renal failure in 1 patient (4.7\%). When the hospital stay was evaluated, the shortest period was 8 , and the longest period was 32 days. Patients had fever and respiratory findings at the time of admission or in their follow-up. Empiric antibiotic treatment appropriate for age without waiting for culture results was started in all of the patients. Severe respiratory distress developed in 5 patients who were followed up in the intensive care unit. The patients' day-1 blood counts revealed a mean white blood cell count of $7547 / \mu \mathrm{L}$ (range, 1940-22 170/ $\mu \mathrm{L}$ ), a mean hemoglobin level 
of $12 \mathrm{~g} / \mathrm{dL}$ (range, $10-16 \mathrm{~g} / \mathrm{dL}$ ), and a mean platelet count of $232.142 / \mu \mathrm{L}$ (range, $93.000-674.000 / \mu \mathrm{L}$ ). Seven patients (33.3\%) had leukopenia, $3(14.3 \%)$ had leukocytosis, and 4 (19\%) had anemia. Nine patients (42.9\%) had thrombocytopenia, and 1 patient (4.8\%) had thrombocytosis. Lymphopenia was detected in 9 (42.9\%), neutropenia in $3(14.3 \%)$, and monocytosis in 8 patients (38.1\%). Two patients (9.5\%) had pancytopenia, and 6 patients (28.5\%) had bicytopenia. Leukopenia, Iymphopenia, thrombocytopenia, and monocytosis were the most common conditions in the sample. While the frequency of these findings was significantly reduced in blood count follow-ups, the incidence of thrombocytosis increased. On day 7, thrombocytosis was detected in 10 of the patients (47.6\%), making it the most frequent finding. It was observed that the clinical course was better in pati- ents who developed thrombocytosis in their followup (Table 1).

Three patients who had underlying chronic disease or respiratory distress, died during the follow-up period because of multiple-organ failure and disseminated intravascular coagulation (DIC). When these patients' blood counts were examined, thrombocytopenia was detected in 2 patients on day 7 , even though these patients had no cytopenia on day 1 . For the other patient, thrombocytopenia had developed from day 11.

Groups 2 and 3 consisted of patients who were hospitalized due to fever, gastroenteritis, respiratory tract infection, and viral agents as detected by serological tests. In Group 2, 10 of the 21 patients (47.6\%) were

Table 1. The frequency of hematologic findings on days 1, 3 and 7.

\begin{tabular}{|c|c|c|c|c|c|c|}
\hline \multirow[b]{2}{*}{ Day } & \multicolumn{2}{|l|}{1} & \multicolumn{2}{|l|}{3} & \multicolumn{2}{|l|}{7} \\
\hline & patients $\mathrm{n}$ & $\%$ & patients $\mathrm{n}$ & $\%$ & patients $n$ & $\%$ \\
\hline Leucopenia & 7 & 33.3 & 5 & 23.8 & 1 & 4.7 \\
\hline Leucocytosis & 3 & 14.3 & 2 & 9.5 & 3 & 14.3 \\
\hline Neutropenia & 3 & 14.3 & 4 & 19 & 1 & 4.7 \\
\hline Lymphopenia & 9 & 42.9 & 4 & 19 & 1 & 4.7 \\
\hline Monocytosis & 8 & 38.1 & 4 & 19 & 4 & 19 \\
\hline Anemia & 4 & 19 & 5 & 23.8 & 2 & 9.5 \\
\hline Thrombocytopenia & 9 & 42.9 & 7 & 33.3 & 3 & 14.3 \\
\hline Thrombocytosis & 1 & 4.8 & 4 & 19 & 10 & 47.6 \\
\hline
\end{tabular}

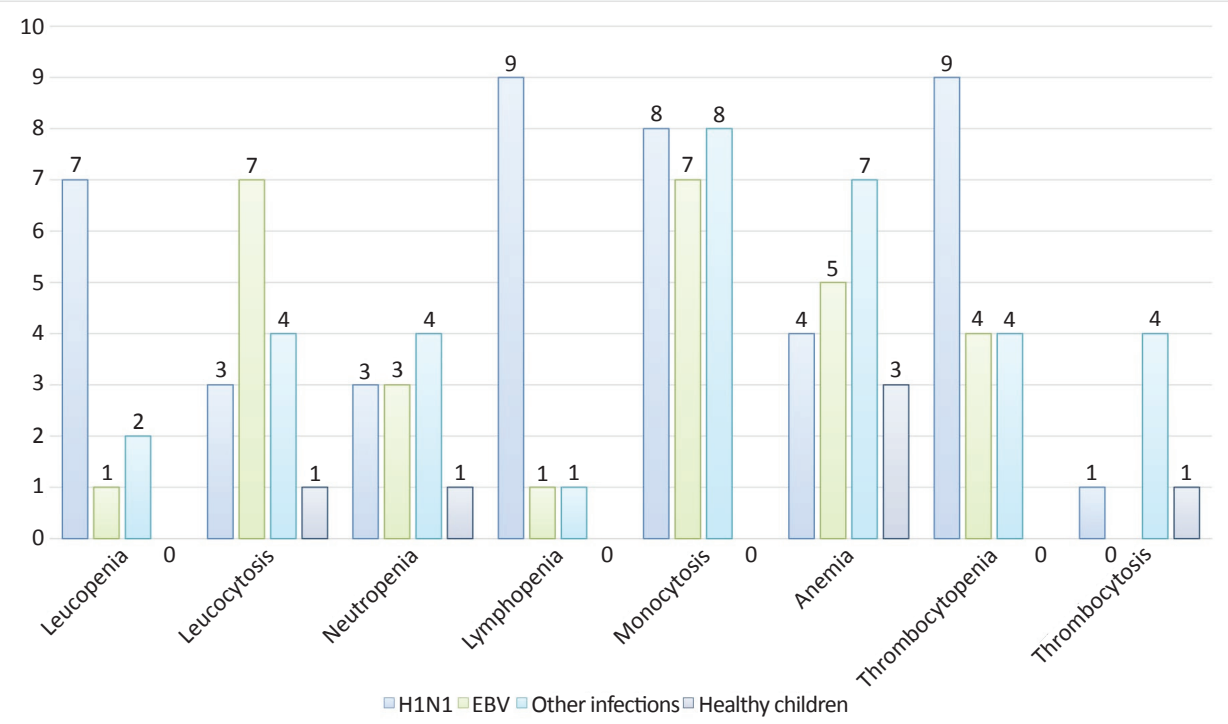

Figure 1. Hematological findings according to groups. 
Table 2. Comparison of hematological findings of H1N1 infection with other groups.

\begin{tabular}{|c|c|c|c|c|c|c|c|c|c|c|c|}
\hline & \multicolumn{2}{|c|}{$\begin{array}{c}\text { H1N1 } \\
\text { (Group 1) }\end{array}$} & \multicolumn{2}{|c|}{$\begin{array}{c}\text { EBV } \\
\text { (Group 2) }\end{array}$} & \multicolumn{2}{|c|}{$\begin{array}{c}\text { Other infections } \\
\text { (Group 3) }\end{array}$} & \multicolumn{2}{|c|}{$\begin{array}{l}\text { Healthy children } \\
\text { (Group 4) }\end{array}$} & \multirow[b]{2}{*}{ p1 } & \multirow[b]{2}{*}{ p2 } & \multirow[b]{2}{*}{ p3 } \\
\hline & $\mathbf{N}$ & $\%$ & $\mathbf{N}$ & $\%$ & $\mathbf{N}$ & $\%$ & $\mathbf{N}$ & $\%$ & & & \\
\hline Leucopenia & 7 & 33.3 & 1 & 4.8 & 2 & 9.5 & 0 & 0.0 & 0.050 & 0.132 & 0.013 \\
\hline Leucocytosis & 3 & 14.3 & 7 & 33.3 & 4 & 19.0 & 1 & 4.8 & 0.278 & 0.996 & 0.601 \\
\hline Neutropenia & 3 & 14.3 & 3 & 14.3 & 4 & 19.0 & 1 & 4.8 & 0.659 & 0.996 & 0.601 \\
\hline Lymphopenia & 9 & 42.9 & 1 & 4.8 & 1 & 4.8 & 0 & 0.0 & 0.011 & 0.011 & 0.003 \\
\hline Monocytosis & 8 & 38.1 & 7 & 33.3 & 8 & 38.1 & 0 & 0.0 & 0.998 & 0.751 & 0.006 \\
\hline Anemia & 4 & 19.0 & 5 & 23.8 & 7 & 33.3 & 3 & 14.3 & 0.998 & 0.482 & 0.996 \\
\hline Thrombocytopenia & 9 & 42.9 & 4 & 19.0 & 4 & 19.0 & 0 & 0.0 & 0.179 & 0.179 & 0.003 \\
\hline Thrombocytosis & 1 & 4.8 & 0 & 0.0 & 4 & 19.0 & 1 & 4.8 & 0.994 & 0.345 & 0.470 \\
\hline
\end{tabular}

female, and 11 (52.3\%) were male. The mean age of the patients was $3.3 \pm 1.5$ years. The youngest patient was 9 months, and the oldest patient was 7 years old. In Group 3, thirteen of the 21 patients (61.9\%) were female, and eight (38\%) were male. The mean age was $5.2 \pm 2.9$ years. The youngest patient was 1 year old, and the oldest patient was 11 years old. When the results of blood count on Day 1 of patients with H1N1 infection were compared in terms of the frequency of hematologic findings, the incidence of lymphopenia was found to be significantly higher than group-2 and group-3 (Figure 1). There was a statistically significant difference in the distributions of leucopenia, lymphopenia, monocytosis and thrombocytopenia among the healthy children's group (Table 2). Group 4 had similar demographic characteristics as Group 1 in terms of age and gender.

\section{DISCUSSION}

The clinical pattern of H1N1 infection can range from a mild upper respiratory tract infection to a lifethreatening, severe disease ${ }^{5}$. In a study of 1088 patients with H1N1 infections, Louie et al. ${ }^{6}$ reported that cough, respiratory distress, nausea, vomiting, muscle ache, sore throat, diarrhea, and headache were the most common symptoms. The mean age of our patients was 5.1 years, and 15 patients (71\%) were under 5 years of age. The most common complaints were fever, sore throat, cough, respiratory distress, and abdominal pain. The mean time between the onset of the patients' complaints and their hospital admission was 2 days (range, 1-4 days). Severe ill- nesses and complications can be seen, especially in infants, children with underlying chronic diseases, and immunosuppressed children ${ }^{5}$. The risk factors identified by the World Health Organization for H1N1 include hemoglobinopathies and malignancies ${ }^{7}$. In a study which evaluated 98 pediatric patients with leukemia, eight patients were diagnosed with H1N1 infection, and they reported that one of them had developed pneumonia and acute respiratory distress syndrome (ARDS) and died ${ }^{8}$. In the epidemic of December 2015 through January 2016, H1N1 infections were not observed among the patients in our Hematology and Oncology clinic who had hemoglobinopathy or malignant disease thanks to the precautions taken. Hardelid et al. ${ }^{9}$ reported that children with high-risk conditions accounted for 1540 admissions (78.5\%) among 1778 children. It accounted for the four fifths of influenza-related PICU admissions occurred in children with high-risk conditions. Uda et al. ${ }^{10}$ reported that among 66 patients with diagnosis of H1N1 infection 12 patients (57\%) were admitted to the pediatric intensive care unit, 7 (33\%) cases required mechanical ventilation. Ten patients $(47 \%)$ had underlying chronic diseases such as neurological diseases, chronic lung diseases, and chronic renal failure. Twelve of our 21 patients (57.1\%) had one or more risk factors, while five of these patients were followed up in the intensive care unit due to respiratory distress and required mechanical ventilation support. When hematological findings of these patients were evaluated, we observed that cytopenias were more severe. 
Cytopenias can develop during viral infections due to cytokine release, drug side effects, decreased production because of bone marrow suppression, or hemolysis. They can also develop due to immunological etiologies ${ }^{11}$. Cytopenias are severe and long-lasting, especially in cases related to hematological diseases that affect the bone marrow, thus resulting in high mortality rates. Hematologic manifestations occur in the acute phase of H1N1 infections, as seen in Epstein-Barr virus, cytomegalovirus, and parvovirus B19 infections ${ }^{4,11}$. In our study, patients had leukopenia $(n=7)$, neutropenia $(n=3)$, patients lymphopenia $(n=9)$, leukocytosis $(n=3)$, and thrombocytopenia $(n=9)$. These rates largely had been reduced by day 7 , and the most common finding in this period was thrombocytosis (10 patients). When first day results were compared with the other groups, the incidence of lymphopenia was found to be significantly higher than Groups 2 and 3. This high incidence of lymphopenia suggests that it may play a role in the severe illness caused by other viral agents.

Hematologic disorders, such as concomitant leukopenia and neutropenia, can lead to more severe infections or to secondary bacterial infections. Secondary bacterial infection plays an important role in the course of the disease. Streptococcus pneumoniae and Staphylococcus aureus are the most common pathogens ${ }^{12}$. The fever was present in the majority of patients at the time of admission. Fever was seen during the follow-up period of a small group of patients who had no fever on admission. Due to the high mortality and the risk of secondary bacterial infections associated with H1N1 infections, empirical antibiotic therapy appropriate to the age of the patients was initiated. The duration of treatment was set to 7-21 days, according to the laboratory and clinical findings of the patients. Although antibiotic treatment is thought to have no effect on the initial blood count, treatment of secondary bacterial infections is thought to mitigate the current clinical situation and affect hematological recovery time.

Thrombocytopenia and thrombocytosis were the most common findings in the study. On day 1 , nine patients (42.9\%) had thrombocytopenia. On day 7, thrombocytosis was detected in 10 patients (47.6\%). Three patients (all of whom had underlying chronic diseases) died due to DIC and multiple-organ failure. Although the first blood counts were normal in 3 patients, the thrombocytopenia developed during the follow-up period, and the general condition deteriorated and they died in the $2^{\text {nd }}$ week. Unlike the patients who developed thrombocytopenia, significant improvement was observed in clinical findings in patients who developed thrombocytosis.

In H1N1 infections, hemophagocytosis can occur in addition to cytopenias. In one study, deaths due to H1N1 infection were reported in 2 (2/31) patients with hematologic malignancies. Both of these patients received the diagnosis of acute lymphoblastic leukemia, and 1 of them developed hemophagocytic lymphohistiocytosis $(\mathrm{HLH})^{4}$. We did not consider HLH for our patients because they did not meet the diagnostic criteria, although some of them developed cytopenia and fever during follow-up period.

Antiviral therapy is recommended only for those who have a known or proven H1N1 virus infection, or if the risks of complications and mortality are at a high level. Early initiation of antiviral therapy has been found to be important in the treatment of the disease $\mathrm{e}^{1,13}$. Our patients received oseltamivir for 5 days at the normal treatment doses. We screened patients at our hospital who had only moderate or poor general health status for H1N1 infection. Therefore, neither hematologic findings in children with mild-to-severe infections, nor remotely monitored information about the effects that oseltamivir has on hematological findings were available.

In conclusion, hematological findings vary for patients during the first week of H1N1 infections. Frequent and more severe course of cytopenias in H1N1 infections may cause the clinical course to be more severe. For this reason, examination of hematological findings in larger patient series may provide information about the prognosis and course of the disease. 


\section{REFERENCES}

1. Jain R, Goldman RD. Novel influenza A (H1N1). Clinical presentation, diagnosis, and management. Pediatr Emer Care. 2009;25:791-6. https://doi.org/10.1097/PEC.0b013e3181c3c8f8

2. Sullivan SJ, Jacobson RM, Dowdle WR, Poland GA. 2009 H1N1 influenza. Mayo Clin Proc. 2010;85:64-76. https://doi.org/10.4065/mcp.2009.0588

3. American Academy of Pediatrics Committee on Infectious Diseases. Antiviral therapy and prophylaxis for influenza in children. Pediatrics. 2007;119:852-60. https://doi.org/10.1542/peds.2007-0224

4. Unal S, Gökçe M, Aytaç Elmas S, et al. Hematological consequences of pandemic influenza H1N1 infection: a single center experience. Turk J Pediatr. 2010;52:570-5.

5. Hackett S, Hill L, Patel J, et al. Clinical characteristics of paediatric H1N1 admissions in Birmingham, UK. Lancet. 2009;374:605. https://doi.org/10.1016/S0140-6736(09)61511-7

6. Louie JK, Acosta M, Winter K, et al. Factors associated with death or hospitalization due to pandemic 2009 influenza $A$ (H1N1) infection in California. JAMA. 2009;302:1896-902. https://doi.org/10.1001/jama.2009.1583

7. World Health Organization (WHO). WHO guidelines for pharmacological management of pandemic (H1N1) 2009 influenza and other influenza viruses. Geneva, Switz: World Health Organization; 2009. (Accessed date: 16.01.2010.)

8. Yöntem $Y$, Ilker D, Yeşim $O$ et al. Analysis of fatal cases of pandemic influenza $A(H 1 N 1)$ virus infections in pediatric patients with leukemia. Pediatr Hematol Oncol. 2013;30(5):437-44. https://doi.org/10.3109/08880018.2013.796025

9. Hardelid P, Kapetanstrataki M, Norman L et al. Characteristics and mortality risk of children with life-threatening influenza infection admitted to paediatric intensive care in England 2003-2015. Respir Med. 2018;137:23-9. https://doi.org/10.1016/j.rmed.2018.02.012

10. Uda K, Shoji K, Koyama-Wakai C et al. Clinical characteristics of influenza virus-induced lower respiratory infection during the 2015 to 2016 season. J Infect Chemother. 2018;24(6):407-13. https://doi.org/10.1016/j.jiac.2018.01.002

11. Grace RF. Hematological manifestations of systemic diseases. Infections. In: Nathan DG, Oski FA, (eds). Hematology of Infancy and Childhood. $7^{\text {th }}$ ed. Philadelphia: Saunders Elsevier, 2009: 1696-705.

12. Rodríguez A, Alvarez-Rocha L, Sirvent JM, et al. Recommendations of the Infectious Diseases Work Group (GTEI) of the Spanish Society of Intensive and Critical Care Medicine and Coronary Units (SEMICYUC) and the Infections in Critically III Patients Study Group (GEIPC) of the Spanish Society of Infectious Diseases and Clinical Microbiology (SEIMC) for the diagnosis and treatment of influenza A/H1N1 in seriously ill adults admitted to the Intensive Care Unit. Med Intensiva. 2012;36:103-37. https://doi.org/10.1016/j.medin.2011.11.020

13. Centers for Disease Control and Prevention (CDC). H1N1 flu. Updated interim recommendations for the use of antiviral medications in the treatment and preventio of influenza for the 2009-2010 season. Atlanta, GA: Centers for Disease Control and Prevention; 2009. (Accessed date: 16.01.2010) 